\title{
Meizothrombin Preparation and Its Role in Fibrin Formation and Platelet Aggregation
}

\author{
Dar'ya S. Korolova*, Tamara M. Chernyshenko, Olga V. Gornytska, \\ Volodymyr 0. Chernyshenko, Tatiana N. Platonova \\ Palladin Institute of Biochemistry of NAS of Ukraine, Kyiv, Ukraine \\ Email: ${ }^{\text {d.korolova@gmail.com }}$
}

Received 11 April 2014; revised 17 May 2014; accepted 28 May 2014

Copyright (C) 2014 by authors and Scientific Research Publishing Inc.

This work is licensed under the Creative Commons Attribution International License (CC BY). http://creativecommons.org/licenses/by/4.0/

c) (†) Open Access

\begin{abstract}
Meizothrombin (MT) is one of prothrombin derivatives which appears in haemostasis activation area. However, its role in haemostasis regulation isn't clear. We studied the role of MT in fibrin formation, platelet activation and aggregation. A new effective method of obtaining MT from native human prothrombin was developed using immobilised prothrombin activator from Echis multisquamatis venom. The protein was stable and electrophoretically pure. Platelet-rich plasma for aggregation study and gel-sieved platelets for flow-cytometry were separated from blood of healthy donors. It was shown that MT transformed fibrinogen to fibrin and activated clotting factor XIII. MT didn't activate gel-sieved intact platelets, but in platelet-rich plasma, increased platelet aggregation induced by ADP, collagen and adrenalin.
\end{abstract}

\section{Keywords}

Prothrombin, Meizothrombin, Platelets, Fibrin Polymerization

\section{Introduction}

Prothrombin (FII) is the precursor of thrombin (FIIa), a multifunctional enzyme that possesses a crucial role in haemostasis: converts fibrinogen to fibrin, activates platelets and endothelium and a number of clotting factors such as protein C and TAFI etc. FII is composed of N-terminal Gla-domain, 2 kringle domains and C-terminal catalytic domain. The prothrombinase complex (Xa and Va factors assembled on phospholipid (PL) membranes in the presence of $\mathrm{Ca}^{2+}$ ) converts FII to FIIa by two pathways. Initial cleavage at Arg320 between the A and B chains generates meizothrombin (MT) which is an active intermediate. The alternative initial cleavage at Arg271 cleaves off the Gla-domain and the two kringles and generates inactive prethrombin-2. Active FIIa is formed as

"Corresponding author. 
a result of following cleavage of intermediates. Both the PL composition of platelet membranes and the conformation of prothrombinase are assumed to govern the pathway choise in vivo [1]-[5].

MT molecule consists of the membrane-binding Gla-domain and catalytic domain with fully formed active site [6]. Therefore MT possesses thrombin-like functions (activates protein C, TAFI, clotting factors V, VIII and XI, etc.). But unlike FIIa, it also binds to membranes [6]-[11]. It was shown that $30 \%$ - $40 \%$ of the active enzyme that is formed on phospholipid membranes and released by prothrombinase is meizothrombin [4]. Mann et al. also speculate that MT pathway is promoted in case of PL pathology (for example, atherosclerotic plaque rupture) [4].

Thus MT is located in the haemostasis activation area and might be able to take part in its regulation. The aim of the present research was to study the role of meizothrombin in fibrin formation and platelet activation/aggregation.

\section{Materials and Methods}

\subsection{Materials}

Activator of prothrombin from Echis multisqumatis venom (ecamulin) was purified by the method of Solovjev et al. as described previously [12].

Prothrombin was isolated from human blood plasma as described in [13].

Fibrinogen was isolated from human blood plasma as described in [14].

\subsection{SDS-PAGE}

The molecular weights and purity of proteins were determined using SDS-PAGE (10\%) by Laemmli [15]. The molecular-weight standard proteins used were SM0671, from Fermentas (Lithuania) and the range was 7 - 170 $\mathrm{kDa}$.

\subsection{Meizothrombin Stability}

Meizothrombin stability was monitored by SDS-PAGE electrophoresis using $12 \%$ acrylamide gel during 30 min incubation of MT in TBS with $1 \mathrm{mM} \mathrm{CaCl}_{2}$ at $37^{\circ} \mathrm{C}$.

\subsection{Fibrinogen Clotting}

Fibrinogen $(0.4 \mathrm{mg} / \mathrm{ml})$ clotting in the presence of FIIa, MT $(0.3 \mathrm{nM})$ was detected in TBS with $1 \mathrm{mM} \mathrm{CaCl}$, at $37^{\circ} \mathrm{C}$ by turbidity study at $350 \mathrm{~nm}$.

\subsection{Factor XIII Activity}

Fibrinogen $(1 \mathrm{mg} / \mathrm{ml})$ with trace amounts of factor XIII was incubated with thrombin in TBS with $0.015 \mathrm{M}$ $\mathrm{CaCl}_{2}$, for $10 \mathrm{~min}$ at $22^{\circ} \mathrm{C}$ for factor XIII activation. Fibrinogen clotting was initiated by thrombin-like enzyme from Agkistrodon halys halys venom (ancistron, $0.25 \mathrm{NIH} / \mathrm{ml}$ ) that clots fibrinogen but doesn't activate factor XIII [16]; the clot was removed and re-solved in $1.5 \mathrm{ml} \mathrm{1.5 \%} \mathrm{acetic} \mathrm{acid} \mathrm{during} 5 \mathrm{~min}$. The concentration of non-cross-linked fibrin dissolved in acetic acid was detected by spectrophotometry at $280 \mathrm{~nm}$. The level of cross-linked fibrin was calculated in percents.

\subsection{Preparation of Platelet-Rich Plasma (PRP) and Gel-Sieved Platelets}

Venous blood was collected from healthy volunteers who had not taken any medication for 7 days. As an anticoagulant we used $38 \mathrm{~g} /$ liter sodium citrate (9 parts blood to 1 part sodium citrate). PRP was obtained by centrifugation blood at $160 \mathrm{~g}$ for $20 \mathrm{~min}$ at $23^{\circ} \mathrm{C}$. Gel-sieved platelets were prepared according to the procedures of Belicer et al. [17] using size-exclusion chromatography on Sepharose 2B (Sigma-Aldrich, US) in 4 mM HEPES,

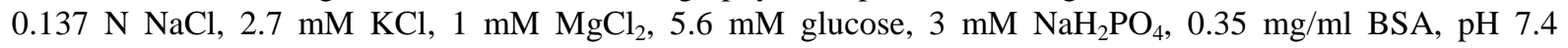
(HEPES-buffer).

\subsection{Platelet Aggregation Study}

Platelet aggregation was measured based on changes in the turbidity of platelet-rich human plasma [18]. We 
employed such experimental parameters as the lag-time between addition of collagen and the beginning of aggregation (lag-phase); the highest percentage of aggregation (rate) and initial speed of aggregation (speed). In typical experiment, $400 \mu \mathrm{l}$ platelet-rich plasma was incubated with $20 \mu 10.025 \mathrm{M} \mathrm{CaCl}_{2}$ and $50 \mu \mathrm{l}$ agonist (ADP 10 or $12.5 \mu \mathrm{M}$; collagen 2 or $3 \mu \mathrm{g} / \mathrm{ml}$; adrenalin 0.8 or $0.6 \mu \mathrm{g} / \mathrm{ml}$ ) at $37^{\circ} \mathrm{C}$. Aggregation was monitored for 10 min. ADP, collagen, adrenaline were from Tekhnologia-standard (Russia).

\subsection{Activation of Gel-Sieved Platelets}

Activation of Gel-Sieved Platelets was detected by flow-cytometry on COULTER EPICS XL Flow-Cytometer. Gel-sieved platelets suspension ( $1 \mathrm{ml}, 150$ - 250 cells) was incubated with $0.5 \mathrm{ml}$ of FIIa, or MT (0.28 and 0.75 $\mathrm{nM} /$ probe) at $37^{\circ} \mathrm{C}$ during 20 min. Flow-cytometry profiles were based on cell size (forward angle light scatter) and cell granularity (side angle light scatter) during platelet activation [19].

\section{Results}

\subsection{Meizothrombin Preparation}

MT is a rather labile protein, which can be turned into thrombin by autocatalysis. All previous data of MT were obtained using recombinant MT that is resistant to autocatalytic removal of fragment 1 [6] [8] or in the presence of a specific, reversible active-site inhibitor dansylarginine N-(3-ethyl-1,5-pentanediyl)amide [7]. However, FII and FIIa are mobile molecules, so amino acid replacement can lead to structure changes and functional variation. We developed a method to get intact MT suitable for in vitro investigations.

For MT preparation, we used ecamulin (prothrombin activator from Echis multisquamatis venom) [20] [21] because it selectively cleaved FII at Arg320 with MT formation (Figure 1(a)). MT was prepared from human FII using ecamulin immobilized on BrCN-Sepharose (Amersham Biosciences, Sweden). Ecamulin was enzymatically active after immobilization. For standardization of ecamulin-Sepharose we used chromogenic substrate S2302 (D-Pro-Phe-Arg-pNA, Chromogenix, Sweden): 1 unit of ecamulin-Sepharose cleaved S2302 with $4.5 \mu \mathrm{M} / \mathrm{min}$ pNA release.

To obtain MT, $1 \mathrm{mg}$ of FII was incubated with 20 units of ecamulin-Sepharose in TBS with $0.2 \mathrm{mM} \mathrm{CaCl}_{2}$ and $1 \mathrm{mM}$ benzamidine during $15 \mathrm{~min}$ at $22^{\circ} \mathrm{C}$. A reversible inhibitor of thrombin, benzamidine, was used to protect MT from autocatalysis. The protein was purified from benzamidine by chromatography on PD-10 (Amersham biosciences, Sweden) ex temporo.

The chromogenic substrate of thrombin S2238 (H-D-Phe-Pip-Arg-pNA, Chromogenix) was used for detection of the formation of active site in MT molecule (Figure 1(b)).
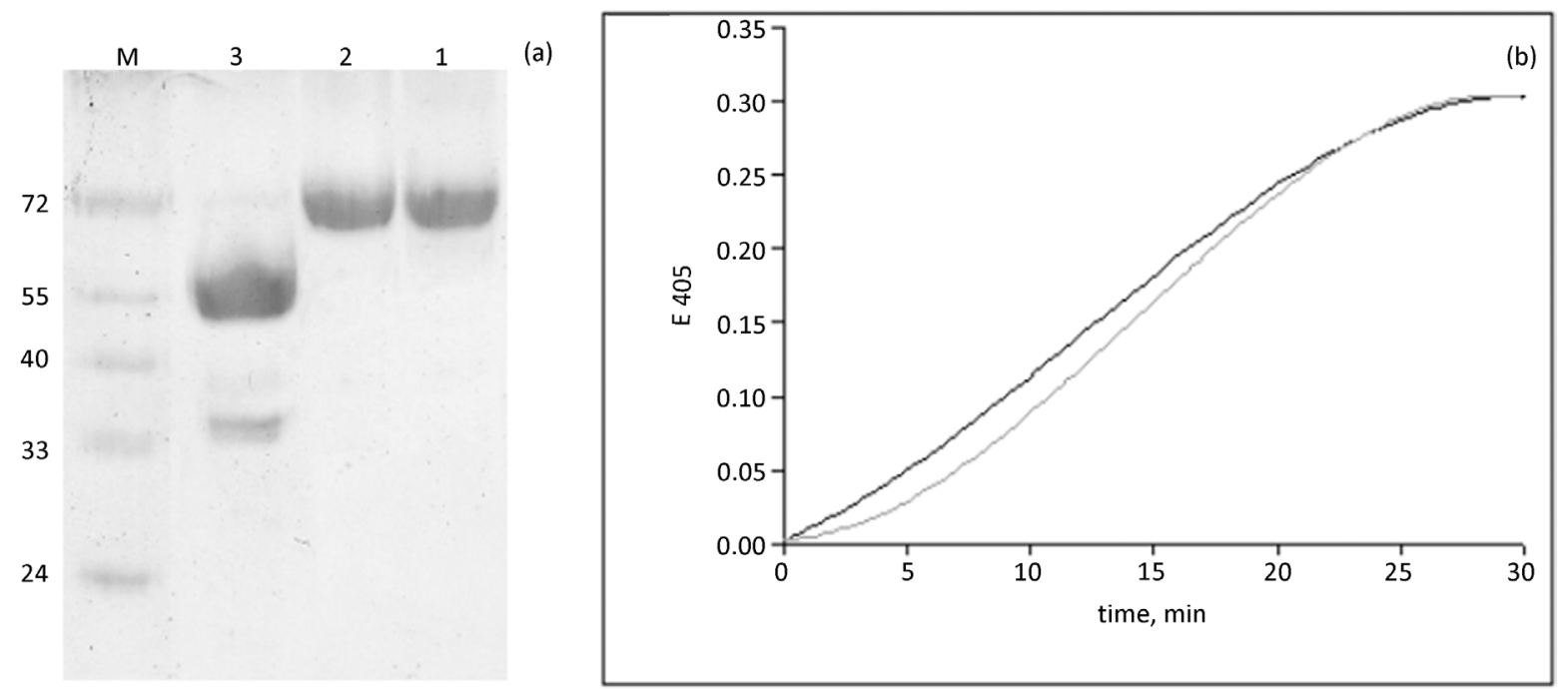

Figure 1. (a) SDS-PAGE (10\%) of the FII activated by ecamulin-Sepharose during 30 minute incubation in TBS with 1 mM $\mathrm{CaCl}_{2}$ and $1 \mathrm{mM}$ benzamidine at $22^{\circ} \mathrm{C}$. $\mathrm{M}$-molecular weight markers. $1-\mathrm{FII}, 2-\mathrm{MT}, 3-\mathrm{MT}$ under reducing conditions $(6$ $\mu \mathrm{g} / \mathrm{ml}$ ); (b) MT (grey) and FIIa (black) activity against low-molecular chromogenic substrate S2238. 
Obtained MT remained stable in TBS with $1 \mathrm{mM} \mathrm{CaCl}_{2}$ at $37^{\circ} \mathrm{C}$ during 30 minutes. Such MT was suitable for research in model systems in vitro. In further experiments we used lower concentrations of MT.

\subsection{Fibrin Polymerization}

The main functions of FIIa during fibrin polymerization are the transformation of fibrinogen to fibrin and activation of factor XIII, which provides formation of cross-linked fibrin clot. We measured the clotting activity of FIIa and MT by turbidity study.

MT was able to induce fibrin formation but the lag-phase of this process was distinctly longer than in the case of thrombin-induced polymerization (Figure 2(a)).

Another important process in the formation of polymeric fibrin is cross-linking by the factor XIIIa. Also, we studied the ability of MT to activate factor XIII, which so far had been neglected [8]. Fibrin polymerization was induced by thrombin-like enzyme ancistron that did not activate factor XIII by itself [22]. MT and FIIa were added to the mixture before ancistron. The amount of cross-linked fibrin was evaluated by measuring the noncross-linked fibrin that was dissolved in 1.5\% acetic acid. It was shown that MT was able to activate factor XIII but was much less effective than FIIa (Figure 2(b)).

\subsection{Platelet Activation and Aggregation}

FIIa activates platelets and triggers their aggregation, by cleaving the N-terminal region of G-protein-coupled protease-activated receptors (PARs). On the other hand, the platelet membrane glycoprotein GPIb acts as a thrombin-binding site and promotes platelet activation by decreasing thrombin concentrations locally [23].

The role of MT in this process is still unknown [8]. We used washed human platelets and platelet rich plasma (PRP) to study MT's influence on platelets.

Flow-cytometry showed no changes of shape and granularity of platelets in the presence of MT, though the protein didn’t activate washed human platelets (Figure 3). At the same time FIIa effectively activated washed human platelets.

The aggregation of platelets in PRP was also studied. MT induced platelet aggregation but was less effective in comparison to FIIa (Figure 4). Platelet aggregation induced by MT was reversible (Figure 4(a)). On the next stage irreversible platelet aggregation followed. Platelet aggregation in PRP was induced by MT in a concentration-dependent manner (Figure 4(b)).

To characterize the process, we also studied the aggregation of platelets in PRP induced by ADP, collagen and adrenalin. Platelet aggregation is a 2-stage process: First, cell signaling leads to GPIIbIIIa activation and grain release; then fibrin/fibrinogen binds to platelets by GPIIbIIIa, and the content of grains stimulates further platelet activation [24]. The second aggregation wave is characterized by studying of this process in the presence of light stimulants (adrenalin, serotonin, ADP in low concentration). ADP in high concentrations is a strong stimulant and can induce an one-wave irreversible aggregation similarly to FIIa. Only collagen-induced platelet aggregation has lag-phase that was shown to be limited by phospholipase C activation [25].
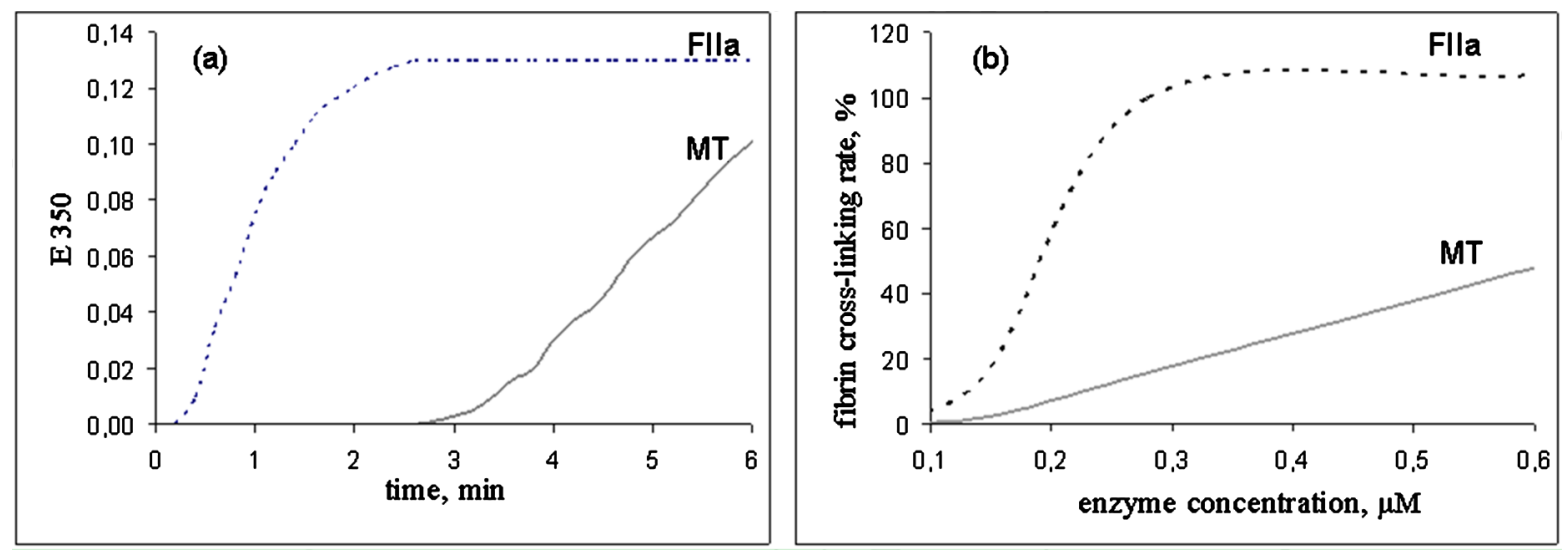

Figure 2. Turbidity study of fibrinogen $(0.4 \mathrm{mg} / \mathrm{ml})$ clotting by FIIa and $\mathrm{MT}(0.3 \mathrm{nM})$ at $37^{\circ} \mathrm{C}(\mathrm{a})$; cross-linking of polymeric fibrin in the presence of FIIa and $\mathrm{MT}$ at $22^{\circ} \mathrm{C}(\mathrm{b})$. 

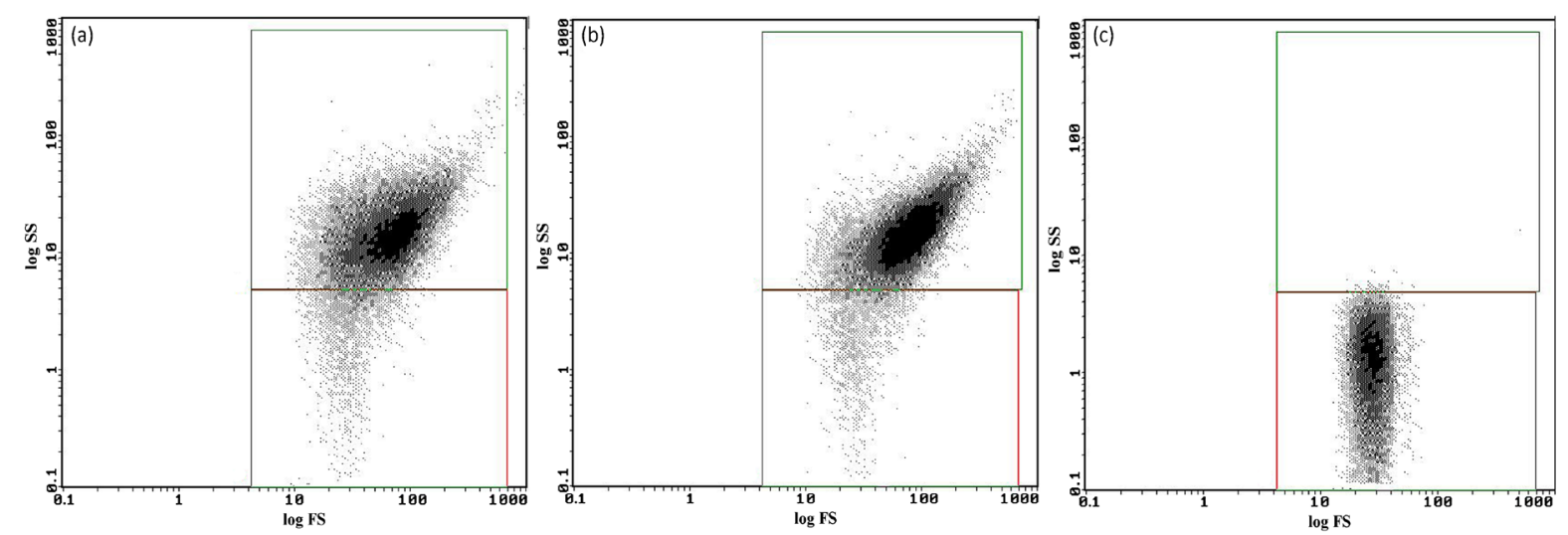

Figure 3. Flow-cytometry of washed human platelets incubated with $0.8 \mu \mathrm{M}$ of MT (b) and with equal volume of TBS as a control (a) during 30 minutes. (c) Platelets activated by thrombin $(0.25 \mathrm{NIH} / \mathrm{ml})$. The distribution of platelets according to the correlation between shape and granulation. Log SS-parameter of platelets granulation: Log FS-parameter of platelets shape.
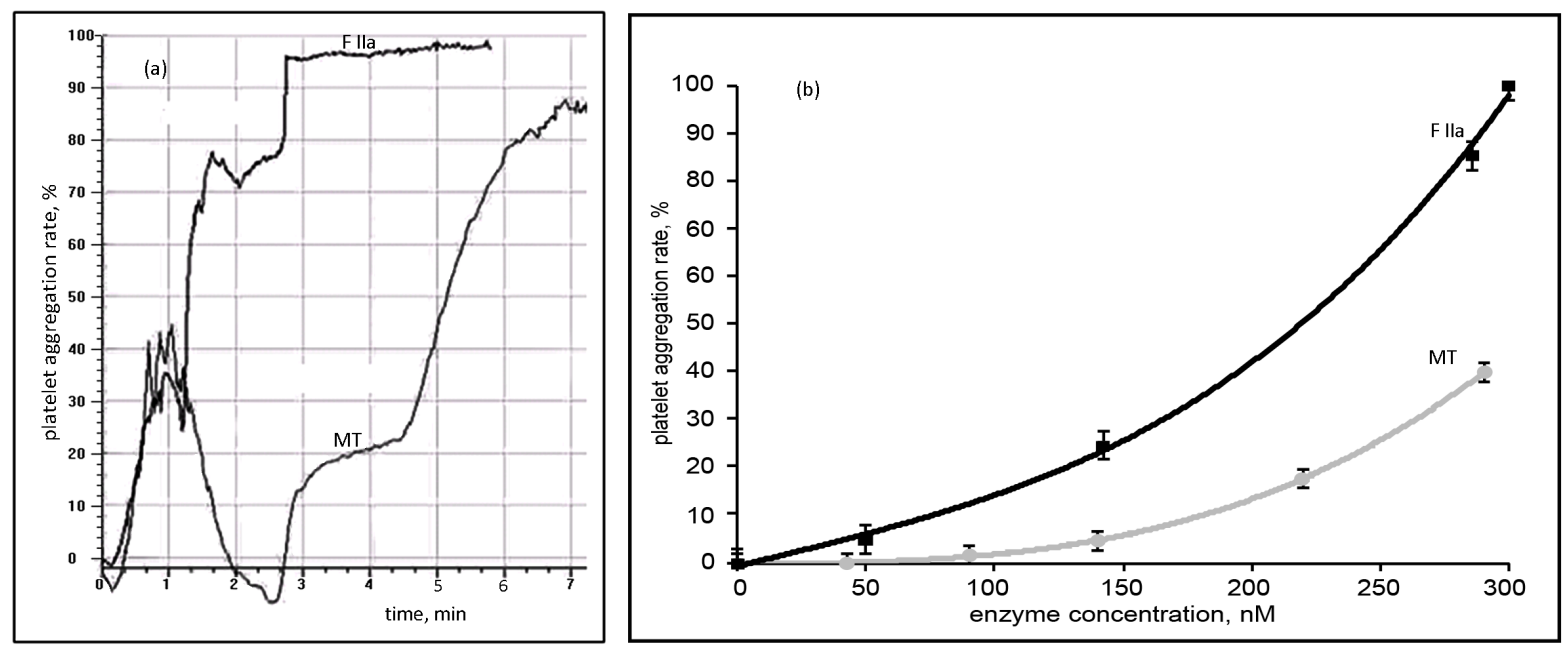

Figure 4. (a) Aggregation rate in platelet rich plasma (PRP), induced by MT (0.29 $\mu \mathrm{M})$ and FIIa at $37^{\circ} \mathrm{C}$; (b) Aggregation in $\mathrm{PRP}$ induced by different concentrations of MT and FIIa at $37^{\circ} \mathrm{C}$.

We studied the aggregation of platelets in PRP induced by different stimulants in the presence of MT (Table 1). Low concentration of MT $(0.1 \mu \mathrm{M})$ that didn't induce platelet aggregation in PRP (Figure 4(b)) increased stimulant-induced platelet aggregation: significantly reduced the lag-phase of collagen-induced platelet aggregation; increased the rate of ADP-induced platelet aggregation; raised the rate and speed of adrenalin-induced platelet aggregation. Thus MT had an enhancing effect on induced platelet aggregation.

\section{Discussion}

A new effective method of obtaining stable MT from native human FII was developed. Active centre formed in molecule of produced MT. As was shown previously, during the first minute of clotting system activation in vitro levels of both FIIa and MT are equal and can reach $0.8 \mu \mathrm{M}$ [2]. Moreover, MT can bind to platelet membrane [8], so local concentration of MT near platelet surface may be significantly increased during the initial activation stage. In our experiments we used the range of concentrations of MT $(0.10-0.75 \mu \mathrm{M})$ that is likely to appear in vivo.

Produced MT probably has no formed exosite I [6] [26] [27] that is why MT slowly cleaved fibrinogen. Therefore MT can interact with fibrinogen/fibrin only by the active site. These data were in agreement with results of Mann et al. who showed that MT has only $10 \%$ of clotting activity in comparison to thrombin [7]. In 
Table 1. Parameters of induced aggregation of platelet rich plasma in the presence of meizothrombin (MT).

\begin{tabular}{rcccccc}
\hline Inductor & \multicolumn{2}{c}{ Collagen $(0.2 \mu \mathrm{g} / \mathrm{ml})$} & \multicolumn{2}{c}{ ADP $(1 \mu \mathrm{M})$} & \multicolumn{2}{c}{ Adrenalin $(60 \mathrm{nM})$} \\
\hline Parameter & lag time, sec & speed, \%/min & rate, $\%$ & speed, \%/min & rate, \% & speed, \%/min \\
\hline Without MT & $40 \pm 1$ & $8 \pm 1$ & $53 \pm 6$ & $70 \pm 5$ & $36 \pm 4$ & $18 \pm 4$ \\
MT $(0.1 \mu \mathrm{M})$ & $10 \pm 2$ & $11 \pm 1$ & $78 \pm 7$ & $63 \pm 6$ & $38 \pm 2$ & $28 \pm 4$ \\
\hline
\end{tabular}

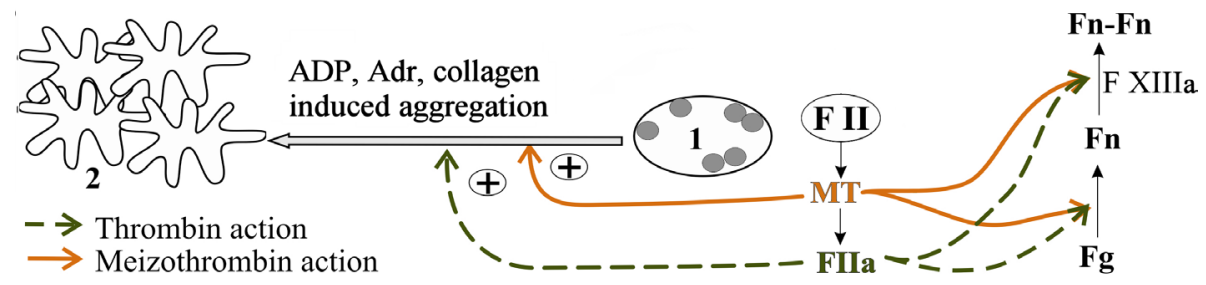

Figure 5. How meizothrombin takes place in clotting: schematic diagram. 1: resting platelet; 2: aggregated platelets; FI: prothrombin; FIIa: thrombin; MT: meizothrombin; Fg: fibrinogen; Fn: monomeric fibrin; Fn-Fn: cross-linked polymeric fibrin; FXIIIa: activated factor XIII.

whole MT poorly stimulated fibrin clot formation by double action: it transformed fibrinogen to fibrin and activated clotting factor XIII (Figure 5). FIIa inhibitor antithrombin III has a significant role in the following activation of coagulation. At the same time it is shown that MT isn't sensitive to antithrombin III [17]. Thus under intensive FIIa inhibition by antithrombin III (e.g., during heparin therapy) MT can also induce thrombus formation.

Results show that MT didn't activate gel-sieved human platelets which are in agreement with data of Côté et al. [6], who showed that MT is an inefficient platelet activator. It can be a result of high cross-reactivity between platelet membrane and PARs for binding with MT. Affinity of FII to PL (Kd = $20-160 \mathrm{nM}$ depending on membrane composition [28]-[30]) is comparable with affinity of FIIa to PARs (Kd = $11-16 \mathrm{nM}$ and $2.9-4.6$ $\mu \mathrm{M}$ depending on receptor type [31] [32]). But FIIa binds to PAR by both active site and exosite I [23] [33]. MT has only the active site so it is more likely to bind to PL than PAR. Simultaneous binding of MT to PL and PAR is complicated due to the short distance between the active site and PL (71 $\AA$ [34]).

Platelet aggregation induced by MT was likely a result of fibrin formation induced by MT. The duration of lag-phase of fibrin formation by MT (Figure 2(a)) was the same as the time of the start of the second platelet aggregation wave (3 min for $0.29 \mu \mathrm{M}$ MT). So irreversible aggregation of PRP stimulated by MT is the result of abnormalities of the fibrin-platelet clot formation, but not only the platelet aggregation. MT is able to induce only reversible aggregation of PRP.

MT didn't activate gel-sieved platelets, but it was able to increase platelet aggregation induced by ADP, collagen and adrenalin (Figure 5). The research allowed us to assume that MT can promote attraction of platelets to clot-formation by stimulating secondary platelet aggregation.

\section{References}

[1] Brufatto, N. and Nesheim, M.E. (2003) Analysis of the Kinetics of Prothrombin Activation and Evidence That Two Equilibrating Forms of Prothrombinase Are Involved in the Process. JBC, 278, 6755-6764. http://dx.doi.org/10.1074/jbc.M206413200

[2] Kim, P.Y. and Nesheim, M.E. (2007) Further Evidence for Two Functional Forms of Prothrombinase Each Specific for Either of the Two Prothrombin Activation Cleavages. JBC, 282, 32568-32581. http://dx.doi.org/10.1074/jbc.M701781200

[3] Orcutt, S.J. and Krishnaswamy, S. (2004) Binding of Substrate in Two Conformations to Human Prothrombinase Drives Consecutive Cleavage at Two Sites in Prothrombin. JBC, 279, 54927-54936. http://dx.doi.org/10.1074/jbc.M410866200

[4] Haynes, L.M., Bouchard, B.A., Tracy, P.B. and Mann, K.G. (2012) Prothrombin Activation by Platelet-Associated Prothrombinase Proceeds through the Prethrombin-2 Pathway via a Concerted Mechanism. JBC, 287, 38647-38655. http://dx.doi.org/10.1074/jbc.M112.407791 
[5] Wood, J.P., Silveira, J.R., Maille, N.M., Haynes, L.M. and Tracy, P.B. (2001) Prothrombin Activation on the Activated Platelets Surface Optimizes Expression of Procoagulant Activity. Blood, 117, 1710-1718. http://dx.doi.org/10.1182/blood-2010-09-311035

[6] Côté, H.C., Stevens, W.K., Bajzar, L., Banfield, D.K., Nesheim, M.E. and MacGillivray, R.T. (1994) Characterization of Stable Form of Human Meizothrombin Derived from Recombinant Prothrombin (R155A, R271A, and R284A). JBC, 269, 11374-11380.

[7] Doyle, M.F. and Mann, K.G. (1990) Multiple Active Forms of Thrombin IV. Relative Activities of Meizothrmbin. JBC, 265, 10693-10701.

[8] Côté, H.C., Bajzar, L., Stevens, W.K., Samis, J.A., Morser, J., MacGillivray, R.T., et al. (1997) Functional Characterization of Recombinant Human Meizothrombin and Meizothrombin (desF1). Thrombomodulin-Dependent Activation of Protein C and Thrombin-Activatable Fibrinolysis Inhibitor (TAFI), Platlet Aggregation, Antithrombin-III Inhibition. JBC, 272, 6194-6200. http://dx.doi.org/10.1074/jbc.272.10.6194

[9] Hackeng, T.M., Tans, G., Koppelman, S.J., de Groot, P.G., Rosing, J. and Bouma, B.N. (1996) Protein C Activation on Endothelial Cells by Prothrombin Activation Products Generated in Situ; Meizothrombin Is Better Protein C Activator than $\alpha$-Thrombin. Biochemical Journal, 319, 399-405.

[10] Tans, G., Nicolaes, G.A., Thomassen, M.C., Hemker, H.C., van Zonneveld, A.J., Pannekoek, H., et al. (1994) Activation of Human Factor V by Meizothrombin. JBC, 269, 15969-15972.

[11] von dem Borne, P.A., Mosnier, L.O., Tans, G., Meijers, J.C. and Bouma, B.N. (1997) Factor XI Activation by Meizothrombin: Stimulation by Phospholipid Vesicles Containing both Phosphatidylserine and Phosphatidylethanolamine. Thrombosis and Haemostasis, 78, 834-839.

[12] Solov'ev, D.A., Platonova, T.N. and Ugarova, T.P. (1996) Isolation and Characteristics of Ekamulin-A Prothrombin Activator from Multiscaled Viper (Echis multisquamatus) Venom. Biokhimiia, 61, 1094-1105.

[13] Mann, K.G. (1976) Prothrombin. Methods in Enzymology, 45, 123-156. http://dx.doi.org/10.1016/S0076-6879(76)45016-4

[14] Varetskaya, T.V. (1960) Microheterogeneity of Fibrinogen. Cryofibrinogen. Ukrainskii Biokhimicheskii Zhurnal, 22, $13-24$.

[15] Laemli, R.V. (1970) Cleavage of Structural Proteins during of Bacteriophage T4. Nature, 227, 680-685. http://dx.doi.org/10.1038/227680a0

[16] Gornitskaia, O.V., Platonova, T.N. and Volkov, G.L. (2003) Enzymes of Snake Venoms. Ukrainskiu Biokhimicheskiu Zhurnal, 75, 22-32.

[17] Belitser, N.V., Anishchuk, M.G., Pozdniakova, T.M. and Gorkun, O.V. (1989) Ultrastructural Changes of Platelets during ADP-Stimulated Aggregation (in the Presence of Fibrinogen). Tsitol Genet, 23, 3-7.

[18] Kahner, B.N., Shankar, H., Murugappan, S., Prasad, G.L. and Kunapuli, S.P., (2006) Nucleotide Receptor Signaling in Platelets. Journal of Thrombosis and Haemostasis, 11, 2317-2326. http://dx.doi.org/10.1111/j.1538-7836.2006.02192.x

[19] Pelagalli, A., Scalia, G., Pero, M.E., Morabito, P., Mastellone, V., Lombardi, P., et al. (2008) Platelets Aggregation and Flow-Cytometry Analysis of Canine Platelet Rich Plasma. Revue de Médecine Vétérinaire, 159, 481-484.

[20] Rochat, H. and Martin-Eauclaire, M.F. (2000) Animal Toxins: Facts and Protocols. Birkhauser Verlag, Basel, 365. http://dx.doi.org/10.1007/978-3-0348-8466-2

[21] Petrovan, R.J., Govers-Riemslag, J.W.P., Nowak, G., Hemker, H.C., Rosing, J. and Tans, G. (1997) Purification and Characterization of Multisquamase, the Prothrombin Activator Present in Echis multisquamatus Venom. Thrombosis Research, 88, 309-316. http://dx.doi.org/10.1016/s0049-3848(97)00258-2

[22] Solov'ev, D.A. and Ugarova, T.P. (1993) Isolation and Characteristics of Alpha-Specific Thrombin-Like Enzymes from Venoms of the Common Pit Viper (Agkistrodon halys halys) and the Eastern Pit Viper (the Central Asian Subspecies Agkistrodon halys blomhoffii). Biokhimiia, 58, 1221-1233.

[23] Brass, L.F. (2003) Thrombin and Platelet Activation. Chest, 124, 18S-25S. http://dx.doi.org/10.1378/chest.124.3_suppl.18S

[24] Savage, B., Cattaneo, M. and Ruggeri, Z.M. (2001) Mechanism of Platelet Aggregation. Current Opinion in Hematology, 8, 270-276. http://dx.doi.org/10.1097/00062752-200109000-00002

[25] Karniguian, A., Grelac, F., Levy-Toledano, S., Legrand, Y.J. and Rendu, F. (1990) Collagen-Induced Platelet Activation Mainly Involves the Protein Kinase C Pathway. Biochemical Journal, 268, 325-331.

[26] Anderson, P.J. and Bock, P.E. (2003) Role of Prothrombin Fragment 1 in the Pathway of Regulatory Exosite I Formation during Conversion of Human Prothrombin to Thrombin. The Journal of Biological Chemistry, 278, 44489-44495. http://dx.doi.org/10.1074/jbc.M306916200

[27] Han, J.H., Côté, H.C.F. and Tollefsen, D.M. (1997) Inhibition of Meizothrombin and Meizothrombin(desF1) by Hepa- 
rin Cofactor II. The Journal of Biological Chemistry, 272, 28660-28665.

[28] Smith, E., Vekaria, R., Brown, K.A. and Longstaff, C. (2013) Kinetic Regulation of the Binding of Prothrombin to Phospholipid Membranes. Molecular and Cellular Biochemistry, 382, 193-201. http://dx.doi.org/10.1007/s11010-013-1735-2

[29] Ellison, E.H. and Castellino, F.J. (1997) Adsorption of Bovine Prothrombin to Spread Phospholipid Monolayers. Biophysical Journal, 72, 2605-2615. http://dx.doi.org/10.1016/S0006-3495(97)78904-5

[30] Govers-Riemslag, J.W., Johnsen, L., Petrovan, R.J., Rosing, J. and Tans, G. (1998) A Kinetic Assay to Determine Prothrombin Binding to Membranes. Thrombosis Research, 92, 239-247. http://dx.doi.org/10.1016/S0049-3848(98)00144-3

[31] Harmon, J.T. and Jamieson, G.A. (1988) Platelet Activation by Thrombin in the Absence of the High-Affinity Thrombin Receptor. Biochemistry, 27, 2151-2157. http://dx.doi.org/10.1021/bi00406a050

[32] Ofosu, F.A. and Nyarko, K.A. (2000) Human Platelet Thrombin Receptors. Roles in Platelet Activation. Hematology/ Oncology Clinics of North America, 14, 1185-1198. http://dx.doi.org/10.1016/S0889-8588(05)70178-7

[33] Adam, F., Guillin, M.C. and Jandrot-Perrus, M. (2003) Glycoprotein Ib-Mediated Platelet Activation. A Signalling Pathway Triggered by Thrombin. European Journal of Biochemistry, 270, 2959-2970. http://dx.doi.org/10.1046/j.1432-1033.2003.03670.x

[34] Armstrong, S.A., Husten, E.J., Esmon, C.T. and Johnson, A.E. (1990) The Active Site of Membrane-Bound Meizothrombin. A Fluorescence Determination of Its Distance from Phospholipids Surface and Its Conformational Sensitivity to Calcium and Factor Va. The Journal of Biological Chemistry, 265, 6210-6218.

\section{List of the Abbreviations}

MT: meizothrombin;

FII: prothrombin;

FIIa: thrombin;

TAFI: thrombin-activatable fibrinolysis inhibitor;

PL: phospholipids;

PAGE: polyacrylamide gel electrophoresis;

SDS: sodium dodecyl-sulfate;

PRP: platelet rich plasma;

PARs: proteinase-activated receptors. 
Scientific Research Publishing (SCIRP) is one of the largest Open Access journal publishers. It is currently publishing more than 200 open access, online, peer-reviewed journals covering a wide range of academic disciplines. SCIRP serves the worldwide academic communities and contributes to the progress and application of science with its publication.

Other selected journals from SCIRP are listed as below. Submit your manuscript to us via either submit@scirp.org or Online Submission Portal.
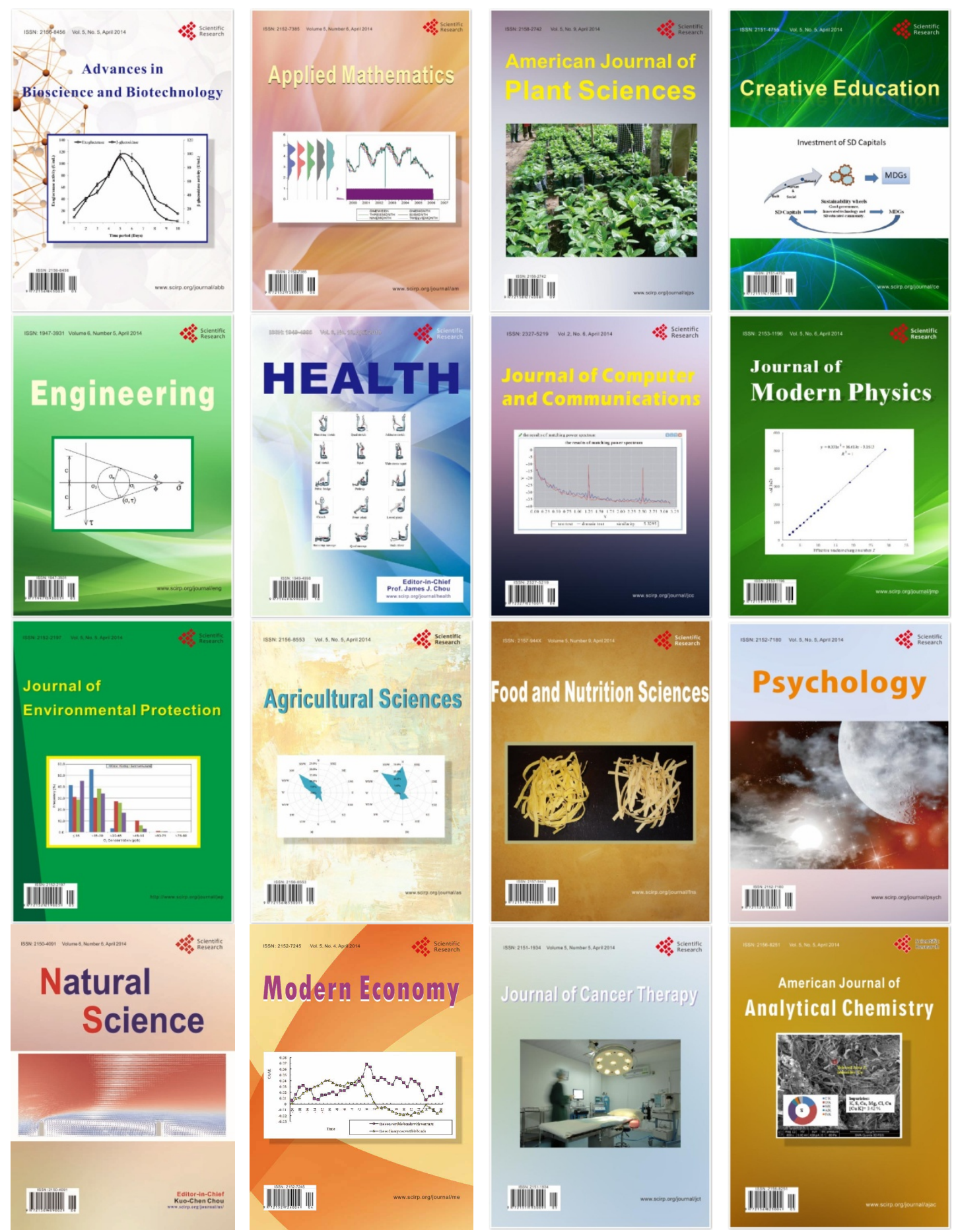